\title{
PRAKTYKI SYMBOLICZNE A TOŻSAMOŚĆ SPOŁECZNA PRACOWNIKÓW SOCJALNYCH
}

\section{Abstract \\ Symbolic pracitces and social identity of social workers}

The paper covers the issue of social workers' social identity taken in theoretical framework of symbolic boundaries by Michèle Lamont and internal-external dialectics of identity by Richard Jenkins. The discussed research concentrated on symbolic practices of social workers in relation towards clients and office workers. Both identified categories sustain the distinction between pure/ impure, however differences can be noticed in case of boundary settings and boundary work. Analysis of external image experienced by social workers and the contrasted self-image connected with social workers/office workers boundary allows for cautious conclusions about prospects of social work professionalization.

Key words: social identity, social workers, symbolic boundaries, symbolic practices

\section{Wprowadzenie}

Początek transformacji systemowej w Polsce stanowi szczególną cezurę dla historii zawodu pracowników socjalnych, wtedy bowiem zaczęły się kształtować zręby dzisiejszego systemu pomocy społecznej, a pracownicy socjalni zostali włączeni do klasyfikacji zawodów (Rataj 2007: 469). Przemiany społeczne nie tylko wygenerowały nowy kontekst, w którym pomoc społeczna stała się istotnym elementem procesu transformacji, lecz przede wszystkim stawiały przed pracownikami socjalnymi nowe zadania. Sprostanie im wiązało się z nabyciem przez pracowników socjalnych nowych kompetencji oraz wiedzy, co przełożyło się na zmiany w profesjonalnym kształceniu (Wódz, Faliszek 2010). Rozwój systemu pomocy społecznej poprzez ustawę i jej kolejne nowelizacje ukształtował strukturę organizacyjną systemu oraz zasady, na jakich wykonywany może być zawód pracownika socjalnego (Brągiel, Kurcz 2002; Matyjas, Porąbaniec 2008).

Przemianom formalnoprawnym towarzyszyła debata nad kwestią profesjonalizacji zawodu (Rataj 2007; Szmagalski 2011; Granosik 2006). Wyczerpujący opis stanowisk oraz wątków związanych z problemem profesjonalizacji pracy socjalnej sam w sobie mógłby 
stać się przedmiotem artykułu o znacznej objętości. Dość wspomnieć, że obejmuje zarówno wątki pełnionych ról społecznych (Trawkowska 2006), kształcenia (Kromolicka 2011; Wódz, Faliszek 2010; Szmagalski 2012), fazy ewolucji zawodu (Zasada-Chorab 2004; Woźniak 1998), jak i samej istoty profesjonalizmu (Kaźmierczak 2011a, 2011b; Wódz 1998). Najistotniejszym, z punktu widzenia celów niniejszego artykułu, wymiarem związanym z problematyką profesjonalizacji zawodu jest kwestia tożsamości (Wódz 1999).

Prowadzone badania nad pracownikami socjalnymi ujawniły, jak dotąd, przede wszystkim biurokratyczno-urzędniczy charakter zawodu:

Pracownicy socjalni w dużej mierze stali się (i prawdopodobnie tak sami się postrzegają) urzędnikami pomocy społecznej odpowiedzialnymi za udzielanie wsparcia socjalnego o charakterze zasiłkowo-usługowym (Rymsza 2011: 240).

Wobec tego byłby to pewien kierunek zmian sprzężony z procesami instytucjonalizacji zawodu i przekształceniami systemu. Alternatywny sposób profesjonalizacji wokół pracy z osobami potrzebującymi wsparcia nie jest, zdaniem badaczy, realizowany lub jest w zaniku.

Porównując - bardzo ogólnie - wyniki badania z roku 2010 z tym sprzed kilkunastu lat, można zauważyć, że praca socjalna, niegdyś zorganizowana w dwa rozłączne schematy (profesjonalny i biurokratyczny), obecnie zunifikowała się wokół jednej biurokratyczno-administracyjnej orientacji działania (Granosik 2012: 191).

Zatem dla określenia pozycji w hierarchii społecznej pracowników socjalnych znaczenie decydujące powinna mieć ich pozycja w strukturze administracyjnej, a tożsamość zawodowa powinna odzwierciedlać urzędniczo-biurokratyczny charakter pracy. Tym samym kwestia profesjonalizacji, a w szczególności wiedzy gromadzonej w trakcie studiów, staje się problematyczna (Kaźmierczak 2012). Badania pokazują jednak pewną dwoistość czy może rozdźwięk między teorią a praktyką pomocy.

Pracownicy socjalni nie mieli wątpliwości, że głównym zadaniem i celem pracy socjalnej jest usamodzielnienie klienta [...]. Stoi to jednak w wyraźnej opozycji do opisu rzeczywistych, codziennych działań skupionych na poprawnym wypełnieniu dokumentacji (Granosik 2011: 103).

$\mathrm{W}$ ten sposób wiedza teoretyczna jako element profesjonalizacji pomocy miałaby nie być odrzucana przez pracowników jako taka, a jedynie „nieprzystająca” do praktyki urzędniczo-biurokratycznej. Obydwie omówione dziedziny wyraźnie z sobą korespondują, rozdźwięk między teorią a praktyką nakłada się bowiem na rozdźwięk między profesjonalnym a biurokratycznym charakterem zawodu i łącznie przyczyniają się do symbolicznego odrzucenia wiedzy teoretycznej oraz dążeń do profesjonalizacji zawodu, a przynajmniej do inkoherencji między tymi wymiarami a doświadczeniem i praktyką pracowników socjalnych. 


\section{Ramy teoretyczne}

Zrekonstruowany w powyższych rozważaniach stan badań stanowił punkt odniesienia dla przyjętego projektu badawczego, którego zasadniczym celem było opisanie i wyjaśnienie praktyk symbolicznych i kulturowych pracowników socjalnych w dwóch zasadniczych zakresach: (1) identyfikacji kryteriów oceniania wartości innych ludzi, którymi posługują się pracownicy socjalni oraz (2) w konsekwencji wyjaśnienia, jak postrzegają hierarchię społeczną i swoje w niej miejsce poprzez interpretację (i podtrzymywanie) różnic między grupą własną a innymi grupami społecznymi i zawodowymi. W zakresie teoretycznym badania odwołują się do koncepcji granic symbolicznych w ujęciu Michèle Lamont $(1992,2000)$ oraz tożsamości społecznej w rozumieniu Richarda Jenkinsa (2008).

Odtworzenie swoistych „gramatyk oceniania” (Lamont, Thévenot 2000), którymi posługiwali się pracownicy socjalni, w zamierzeniu badawczym miało pozwolić na zidentyfikowanie granic symbolicznych (Lamont 1992, 2000) relacyjnie określających ich tożsamość zbiorową. Symboliczne wyznaczenie granicy odwołuje się do tego ,jak ludzie definiują "nas «i »ich «" (Lamont 2001). Ustanowienie granic pozwala na określenie, kim jesteśmy „my” za pomocą różnic oddzielających „nas” od „innych”. Tym samym kluczowym elementem dla określenia tożsamości własnej jest to, kto (jaka grupa) znajdzie się po przeciwnej stronie granicy. Ponadto nie mniej istotnym czynnikiem jest określenie, jakimi kryteriami posłużymy się do oceny owych innych. Jak wykazywała Lamont w kolejnych studiach porównawczych francuskich i amerykańskich robotników (Lamont 2000) oraz przedstawicieli wyższych klas średnich (Lamont 1992), to, wobec kogo granica jest wytyczona i za pomocą jakich kryteriów owe różnice są określane, jest z sobą sprzężone, a repertuary możliwych do wykorzystania kryteriów zróżnicowane kulturowo. Stanowisko Lamont stanowi próbę połączenia elementów konstruowania społecznego świata poprzez praktyki symboliczne (określenie grupy „innych” oraz kryteriów oceniania wykorzystywanych w porównaniach międzygrupowych) z uwzględnieniem strukturalnych ograniczeń (w danym kontekście społeczno-narodowym możliwe jest odwołanie się do określonego i ograniczonego zbioru owych kategorii ocen i autodefinicji (Lamont 1995: 352) ${ }^{1}$. W swoich opracowaniach Lamont przywołuje trzy grupy kryteriów oceny wykorzystywanych w zabiegach hierarchizacji i podtrzymywania granic symbolicznych między klasami i frakcjami klasowymi: socjoekonomiczne, kulturowe i moralne. To właśnie te ostatnie stanowią o oryginalności jej podejścia. Jak zwraca uwagę autorka:

pomimo przyjmowania przez każdą z grup swoich zasad moralnych jako uniwersalnych, każda uprzywilejowuje bardzo odmienne aspekty moralności, odnośnie do tego, co wyróżnia grupę „innych”

${ }^{1}$ Jak wykazała Lamont, odwołanie się do tego samego kryterium „rasowego/etnicznego” może się różnić w zależności od kontekstu kulturowego, np. granica oparta na kryterium rasowym w USA przebiega na linii biali-czarni robotnicy, podczas gdy we Francji na linii biali-imigranci z północnej Afryki. W tym ostatnim przypadku negatywne kryteria oceny imigrantów z północnej Afryki nie są stosowane wobec czarnych robotników, ponieważ granica oparta jest na kryteriach moralnych - w tym wypadku godności (Lamont 2000). 
[...]. To ilustruje, jak skupienie uwagi na zawartości moralnej kryteriów wzbogaca rozumienie procesów tworzenia silnych międzygrupowych granic symbolicznych [tłum. Ł.T.] (Lamont 2001: 178).

Odwołanie się do określonej „zawartości moralnej kryteriów” (np. godności w przypadku robotników) pozwala na zrekonstruowanie odmiennych mechanizmów wykluczenia (np. postrzegania innych jako pozbawionych godności) i konfliktów międzygrupowych. „Wytwarzane granice symboliczne, a za ich sprawą tożsamości, mogą wzmocnić lub osłabić wartości zasobów", np. przez dystansowanie się robotników wobec kryterium statusu społecznego czy sukcesu (Lewicki 2016: 49).

Koncepcja granic symbolicznych związana jest z postrzeganiem tożsamości własnej w kontekście różnic wobec innych. To właśnie rozumienie tożsamości w kategoriach różnic poddaje krytyce Jenkins, który proponuje, by jednakową uwagę w kwestii tożsamości przypisywać podobieństwu i różnicom. Jego zdaniem określenie, od kogo się różnię, oznacza jednocześnie przyznanie, do kogo jestem podobny (Jenkins 2008: 21). Tym samym podobieństwa i różnice w określaniu tożsamości to dwa, splecione z sobą, aspekty tego samego procesu, próba określenia tożsamości „innego" jest bowiem wpisana w odniesienie do własnej autodefinicji. Jednocześnie Jenkins krytykuje rozróżnienie tożsamości grupowej i indywidualnej, gdyż - jego zdaniem - to, co jednostkowe, i to, co zbiorowo podzielane w tożsamości, nie tylko jest istotnie do siebie podobne, lecz także nierozerwalnie splecione, a procesy (w szczególności interakcyjny charakter tożsamości) wytwarzania i przekształcania są jednakowe (Jenkins 2008: 37-38).

Swoją koncepcję tożsamości społecznej Jenkins proponuje rozważać na trzech poziomach: jednostkowym, interakcyjnym i instytucjonalnym. Na poziomie indywidualnym Jenkins, nawiązując do George’a Herberta Meada, proponuje koncepcję wewnętrzno-zewnętrznej dialektyki identyfikacji jednostkowej. Dialektyka ta odnosi się do dwóch biegunowo przeciwstawnych, ale dialektycznie związanych wizerunków jednostki: wewnętrznego (tego, jak jednostka pragnie siebie zaprezentować innym w interakcjach) oraz zewnętrznego (tego, jak jest owa autoprezentacja postrzegana przez innych). Dlatego właśnie tożsamość ma charakter relacyjny, to w toku interakcji bowiem dochodzi do uzgodnienia owych wizerunków: autoprezentacji (moment wewnętrzny) i jej akceptacji lub odrzucenia (moment zewnętrzny) oraz narzucania wizerunku zewnętrznego (etykiet) i ich przyswojenia-odrzucenia przez etykietowanych. Jenkins wyraźnie nawiązuje do teorii etykietowania Howarda Beckera, wprowadzając pojęcie tożsamości nominalnej (narzuconej etykiety) i realnej (tego, jakie znaczenie owa etykieta ma dla jednostki). Tym samym rozważania dotyczące dialektyki wewnętrzno-zewnętrznej zostały przeniesione na poziom instytucjonalny: moment zewnętrzny stanowią kategorie, do których jednostki są zaliczane, a moment wewnętrzny stanowią identyfikacje grupowe jednostki. „Problematyzacja grupowo-kategorialnego rozróżnienia podkreśla centralne znaczenie władzy, a przez to i polityki w podtrzymywaniu oraz zmianie tożsamości” [tłum. Ł.T.] (Jenkins 2008: 43).

Odwołanie się do poziomu zbiorowego prowadzi Jenkinsa do przywołania koncepcji granic symbolicznych, gdyż wyodrębnienie kryteriów członkostwa w grupie utożsamia 
on $\mathrm{z}$ procesem wytyczania owych granic. „Podobieństwa i różnice odzwierciedlają wzajemnie podzielaną granicę. Na granicy odkrywamy, kim jesteśmy w tym, kim nie jesteśmy, i vice versa" [tłum. Ł.T.] (Jenkins 2008: 103). Istotną modyfikacją Jenkinsa jest zwrócenie uwagi na współzależność podobieństwa i różnicy na granicach, podczas gdy Lamont zwracała uwagę głównie na różnice. Specyficznie ujawnia się również podobieństwo, a w zasadzie komplementarność wobec teorii Lamont, gdyż tam, gdzie Lamont odwoływała się do struktur kulturowych w celu określenia zakresu repertuaru możliwych zabiegów klasyfikacji, Jenkins proponuje instytucjonalnie określone relacje władzy.

\section{Zarys metodologii badania}

Przyjęte ramy teoretyczne były związane bezpośrednio z zasadniczym celem badania, jakim było opisanie i wyjaśnienie praktyk symbolicznych pracowników socjalnych. Poznanie, jak pracownicy socjalni wyznaczają granice symboliczne, wobec kogo i za pomocą jakich środków je wytyczają i podtrzymują, było zasadniczym elementem zrozumienia sposobów budowania tożsamości zawodowej. Istotne także stało się określenie, jak doświadczają i jak odnoszą się do narzucanego wizerunku zewnętrznego. Czy go akceptują, czy odrzucają (moment zewnętrzny jaźni)? Jeśli odrzucają, to jaki autowizerunek przeciwstawiają (moment wewnętrzny jaźni)?

W celu zrealizowania tych zamierzeń przeprowadzono 40 wywiadów pogłębionych $\mathrm{z}$ pracownikami socjalnymi i $8 \mathrm{z}$ kierownikami ośrodków pomocy społecznej z terenu województwa śląskiego.

Ośrodki do badania zostały wybrane celowo na podstawie dwóch kryteriów: stopnia wykluczenia i wielkości miejscowości. Stopień wykluczenia wyznaczono stosunkiem odsetka klientów pomocy społecznej do ogółu populacji miejscowości. Wskaźnik ten daleki jest od doskonałości, informuje bowiem tylko o liczbie świadczeniobiorców, co niekoniecznie przekłada się na zakres obciążeń samych pracowników socjalnych. W badaniach przyjęto próg 5\% udziału klientów w populacji jako granicę między ośrodkami o dużym zapotrzebowaniu a ośrodkami o małym zapotrzebowaniu na pomoc (w celu ujednoznacznienia różnic między typami ośrodków nie dobierano takich przypadków, w których odsetek klientów w populacji wynosił między 4,5 a 5\%). Wielkość miejscowości ma znaczenie dla pozycji pracownika socjalnego w środowisku i społeczności lokalnej z racji większej anonimowości w dużych miastach i dużej „gęstości interakcyjnej” w małych miejscowościach. Odmienne też są warunki pracy i stopień nawarstwienia potrzeb, co przyczynia się do stwierdzonych we wcześniejszych badaniach różnic między pracownikami ze względu na wielkość miejscowości, w której pracują (Trawkowska 2006: 358-360). Jako wielkość graniczną między małymi i dużymi miejscowościami przyjęto 50 tys. mieszkańców. Choć wielkość ta jest ustalona nieco arbitralnie, odpowiada różnicy między małymi miasteczkami i wioskami a dużymi miastami. Z powodu umowności owej wartości granicznej 50 tys. ośrodki do badania dobierano w miejscowościach, których liczba mieszkańców jest znacząco mniejsza lub większa od tej wartości (w szczególności 
w przypadku małych miasteczek preferowano np. kilku-, kilkunastotysięczne miejscowości zamiast większych miast powiatowych). Badania realizowano w województwie śląskim we wszystkich subregionach, gdyż sytuacja w subregionie centralnym z dominacją dużych ośrodków miejskich jest zasadniczo odmienna od subregionów północnego i południowego, w których przeważają małe miejscowości.

W rezultacie złożenia obydwu parametrów: wielkości miejscowości i stopnia wykluczenia ośrodki zostały pogrupowane w cztery kategorie: małe ośrodki z niewielkim odsetkiem klientów - 101 gmin, małe gminy o dużym odsetku klientów - 32 gminy, duże ośrodki z małym odsetkiem klientów - 18 gmin i duże gminy o dużym odsetku klientów - 6 gmin. W każdej kategorii przeprowadzono 10 wywiadów z pracownikami socjalnymi i po 2 z kierownikami. W celu uniknięcia powtarzalności odpowiedzi i „przygotowywania się" do wywiadu w każdym ośrodku starano się realizować maksimum 2 wywiady - jeden zaraz po drugim.

Opracowanie materiału poprzedziła transkrypcja całości wywiadów, które za pomocą oprogramowania do badań jakościowych MAXQDA poddano dwukrotnemu kodowaniu: najpierw poszczególne fragmenty wypowiedzi respondentów odnoszące się do stosowanych etykiet, klasyfikacji i doświadczanego wizerunku zostały oznaczone w postaci kodów. Po przeanalizowaniu owych kodów możliwe było stworzenie ich zespołów (kody drugiego rzędu) i hierarchii, w jakie się układały ${ }^{2}$. Utworzone kody zostały wykorzystane przy ponownym przekodowywaniu zebranego materiału. Przy tworzeniu hierarchii kodów odwoływano się do przyjętego języka teoretycznego i dążono do odnalezienia w materiale: grup (i jednostek), wobec których pracownicy socjalni budowali granice (opierając się na schemacie podziału my-oni); określenia cech wspólnych, jakimi definiowali grupę własną (ze szczególnym uwzględnieniem tych cech, które - ich zdaniem - odróżniały pracowników socjalnych od wszystkich zidentyfikowanych ,innych”); oraz kryteriów, jakimi posługiwali się w ocenianiu innych oraz siebie samych (z uwzględnieniem kategorii zaproponowanych przez Lamont). Tak opracowany materiał został poddany analizie, w której dążono do odnalezienia podobieństw i prawidłowości w posługiwaniu się sposobami oznaczania obiektów (innych), kryteriami oceniania (wartościowania) czy ogólnymi zasadami klasyfikacji (podziały, do jakich odwoływały się używane przez badanych klasyfikacje). W niniejszym artykule skupiono się na tym fragmencie zgromadzonego materiału, który odnosił się do tożsamości społecznej pracowników socjalnych³

\footnotetext{
${ }^{2} \mathrm{~W}$ ten sposób próbowano połączyć kodowanie na podstawie danych z kodowaniem na podstawie teorii.

${ }^{3}$ Badanie podstawowe zostało uzupełnione przez obserwację uczestniczącą w jednym z OPS oraz wywiady zogniskowane przeprowadzone z pracownikami i kierownikami OPS po wstępnym opracowaniu materiału zebranego w badaniu głównym.
} 


\section{Granica i jej wymiary}

Po zakończeniu drugiego cyklu kodowania, który operował na wyższym poziomie abstrakcji, dążono do opracowania modelu wyjaśniającego praktyki symboliczne pracowników socjalnych. Głównym elementem owych praktyk było określenie, wobec kogo i na podstawie jakich kryteriów wyznaczana jest granica symboliczna. Poszukiwanie koherencji między poszczególnymi praktykami oceniania ujawniło, że granice między pracownikami socjalnymi a klientami i między pracownikami socjalnymi a grupami $\mathrm{z}$ otoczenia instytucjonalnego, z jakimi wchodzą w kontakt, przebiegają w odmiennych kontekstach, odnoszą się do zróżnicowanych komponentów ocen, systematycznie jednak przejawiają dychotomiczny charakter. Poszukując teoretycznego mechanizmu wyjaśniającego, który odpowiadałby zaobserwowanym danym, odwołano się do antropologicznej koncepcji rozróżnienia czystości i nieczystości Mary Douglas (2007). W analizowanym materiale zaobserwowano nakładanie się stosowanych przez badanych klasyfikacji (por. Bourdieu 2005: 573 i nast.) normalne/nienormalne, wyższe/niższe, moralne/niemoralne (oraz wielu innych) z klasyfikacją czyste/nieczyste.

Według przyjętego modelu (opartego jednak na praktykach oceniania i kategoryzowania stosowanych przez badanych) odróżnienie „świata ludzi normalnych” - takim określeniem posługiwali się badani - od świata klientów ${ }^{4}$ przebiegałoby na granicy czyste/nieczyste. Zgodnie z konceptualizacją Douglas to, co nieczyste, powstaje wskutek „różnicującej aktywności umysłu” i jest produktem ubocznym tworzenia porządku (Douglas 2007: 191). Istotnym czynnikiem jest ścisłe rozdzielenie dwóch przestrzeni społecznych jako światów równoległych. Jedna z respondentek zwerbalizowała to rozróżnienie następująco:

to, co dla nas ${ }^{5}$ się wydaje oczywiste, dla nich [klientów - Ł.T.] po prostu w ogóle nie istnieje, a to, co dla nas jest bulwersujące, dla nich jest zupełnie... zupełną normą [...]. I to są, to są takie właśnie rzeczy, z którymi znowu na nowo uczę się tego, że oni żyją w innym świecie i trzeba po prostu wejść do ich świata, zacząć najpierw trochę myśleć jak oni i wtedy dopiero można próbować jakoś tam im pomóc, chociaż, tak jak mówię, ja uważam, że gros tych ludzi, to są ludzie, którym nie da się w żaden sposób pomóc, bo oni nigdy w życiu nawet nie zbliżą się do tej normalności (PS 30)

Ów świat równoległy, świat nieczystości, jest światem à rebours, światem, w którym reguły „ludzi normalnych” nie obowiązują, a reguły obowiązujące w świecie marginalnym są nieakceptowalne przez uczestników świata normalnego.

${ }^{4}$ Na mocy opozycji świat klientów stałby się światem nienormalnym.

${ }^{5}$ Warto zwrócić uwagę na dwojakie użycie kategorii „my” - dla określenia grupy własnej (pracowników socjalnych) i szerzej, ludzi „normalnych”.

${ }^{6}$ Wywiady z pracownikami socjalnymi zostały oznaczone symbolem PS i numerem przypisanym kolejno respondentom. Wywiady z kierownikami opatrzono symbolem K i odpowiednim numerem. 
Jaka jest pozycja pracowników socjalnych w odniesieniu do owej granicy? Badani jednoznacznie lokują samych siebie na pozycjach czystości (w świecie ludzi normalnych), oddzielając się symbolicznie od klientów. Wiele zabiegów związanych z budowaniem klasyfikacji klientów (w czym znajdują odbicie hierarchizacje dokonywane przez pracowników socjalnych) oraz stosowanych w tych zabiegach kryteriów wartościowania mogłoby posłużyć do przygotowania zupełnie odmiennego artykułu i nie będą tutaj szczegółowo omawiane.

Granice symboliczne nie są prostymi dystynkcjami pozwalającymi na odróżnienie od siebie grup społecznych. Nawet w najprostszych klasyfikacjach, w których jest obecny rozdział czystości i nieczystości, zawarty jest silny komponent oceniający. Co więcej, badania Douglas wykazują, że podział ten jest zabiegiem porządkującym, w którym dokonujący takiego wartościowania jednoznacznie lokują samych siebie w obszarze czystości. Nie zaskakuje więc fakt, że klienci zostali zaliczeni do świata nieczystości. Nieczystość nie oznacza tu tylko dosłownej nieczystości cielesnej, choć tę oczywiście również, ponieważ problemy z czystością ubrań, higieną osobistą czy porządkiem w miejscu zamieszkania były w tym kontekście przywoływane. Podążając tropem myśli Douglas, która uznaje ciało za pierwotny model myślowy, służący ludziom w oznaczaniu rzeczywistości i określaniu granic (np. wewnętrzne/zewnętrzne), odnajdywaliśmy również symboliczne wzorce owej czystości także w sferze moralności, seksualności czy stosunków rodzinnych. Konieczne jest tutaj jednak ważne zastrzeżenie, iż zaobserwowana granica dotyczy części klientów. Kiedy badani odwoływali się do szeroko rozumianych kategorii humanizmu czy wartości ogólnoludzkich, wskazywali na brak istotnych różnic między klientami a pracownikami socjalnymi.

W perspektywie tożsamości społecznej pracowników socjalnych niezwykle ważny jest jednak pewien paradoks przywołanej granicy symbolicznej. Pracownicy socjalni są bowiem tą grupą społeczną, która w swojej pracy przekracza ową granicę i wchodzi w kontakt z grupami osób kategoryzowanych jako nieczyste. Badani pracownicy spontanicznie wskazywali na fakt oceniania ich pracy przez pryzmat tego kontaktu, przywołując metafory choroby (stygmy) i nieczystości.

To się tak przenosi, troszeczkę prątkuję, że tak powiem, to jest taki stan zapalny, że inaczej, o właśnie inaczej jest traktowana osoba, która pracuje w urzędzie (PS 13).

Innymi słowy, pracownicy są skalani kontaktem z owym światem nieczystym. Choć formalnie znajdują się w świecie normalnym, to jednak sam kontakt z nieczystością prowadzi do przeniesienia części tej stygmy (Goffman 2005), owego naznaczenia samych pracowników socjalnych.

Jednocześnie dla samych pracowników ta stygmatyzacja ich zawodu związana z kontaktem $\mathrm{z}$ klientami jest elementem, który łączą z osamotnieniem pracowników socjalnych zarówno w zbiorowości, jak i w relacjach rodzinnych. 
O! Do tej satysfakcji zawodowej można dodać to, czy ktoś mi powie dzień dobry, czy nie - to, czy ktoś się przyzna do tego, że mnie zna, bo to jest wstyd, że się zna pracownika socjalnego [...]. I tak samo jest na spotkaniach rodzinnych. Jest się traktowanym [jakby się było - uzup. Ł.T.] trędowatym (PS 13).

Pracownicy socjalni znajdują się w sytuacji podwójnego uwikłania w granice symboliczne, gdyż sami aktywnie wytyczają i podtrzymują granicę w odniesieniu do klientów (odtwarzając tym samym podział na czyste i nieczyste) i jednocześnie zmuszeni są do konfrontowania się z granicami symbolicznymi wytyczanymi wobec nich przez

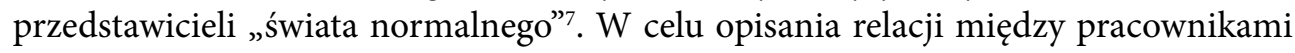
socjalnymi a ich otoczeniem, wizerunku własnego, który prezentują, oraz wizerunku zewnętrznego, którego doświadczają, odwołano się w badaniach do koncepcji dialektyki wewnętrzno-zewnętrznej tożsamości społecznej Richarda Jenkinsa.

\section{Pozycja pracowników socjalnych}

Omówienie momentu zewnętrznego i wewnętrznego tożsamości społecznej pracowników socjalnych musi zostać poprzedzone przywołaniem kilku elementów kontekstowych. Nie towarzyszy temu skróconemu opisowi żadna intencja wyczerpania tematu, a jedynie umieszczenie rozważań w kontekście. W tym celu należy rozpatrzyć pozycję pracowników socjalnych w przestrzeni społecznej analizowanej w trzech wymiarach: wertykalnym rozróżnieniu klas niższych, średnich i wyższych; horyzontalnym zróżnicowaniu frakcji klasowych ze względu na dominujące zasoby kapitału ekonomicznego lub kulturowego i temporalnym ze względu na wznoszącą lub opadającą trajektorię danej grupy społeczno-zawodowej w hierarchii społecznej (Bourdieu 2005: 149-166). W pierwszym $\mathrm{z}$ wymiarów (wertykalnym) pracownicy socjalni lokują się w dolnych warstwach klasy średniej. Wywiady ujawniają, iż pracownicy socjalni aspirują do stylu życia typowego dla klas średnich, ale jednocześnie wskazują na trudności w realizacji owego stylu życia z powodu niskiego poziomu dochodów (dlatego można mówić o aspirowaniu). Pod względem dochodowym pracownicy socjalni znajdują się bowiem poniżej niektórych frakcji klasy robotniczej. Niemniej zajmując typowe dla klas średnich pozycje w hierarchii administracyjnej (pracownicy socjalni mają status urzędników), mogą czerpać swoistą rentę z zasobów zinstytucjonalizowanego kapitału kulturowego oraz swojej pozycji instytucjonalnej (ta jednak ma janusowe oblicze, ponieważ instytucjonalno-biurokratyczna władza wobec klienta niekoniecznie przekłada się na jego szacunek).

Niskie wynagrodzenia pracowników socjalnych znajdują swoje odzwierciedlenie także w wymiarze horyzontalnym (dystrybucji kapitałów kulturowego i ekonomicznego między frakcjami klasowymi). Pracownicy socjalni są bliżsi bieguna kapitału kulturowego (wykształcenie, kierunkowe przygotowanie do pracy), ponieważ opierając się na zasobach tego kapitału, czerpią swoje uzasadnienie pozycji społecznej. Trzeci

\footnotetext{
${ }^{7}$ Kod in vivo.
} 
z wymiarów, temporalny, wpisuje się w dążenia profesjonalizacji pracy socjalnej oraz związanej z tym trajektorii grupy zawodowej w strukturze społecznej i zostanie omówiony w podsumowaniu.

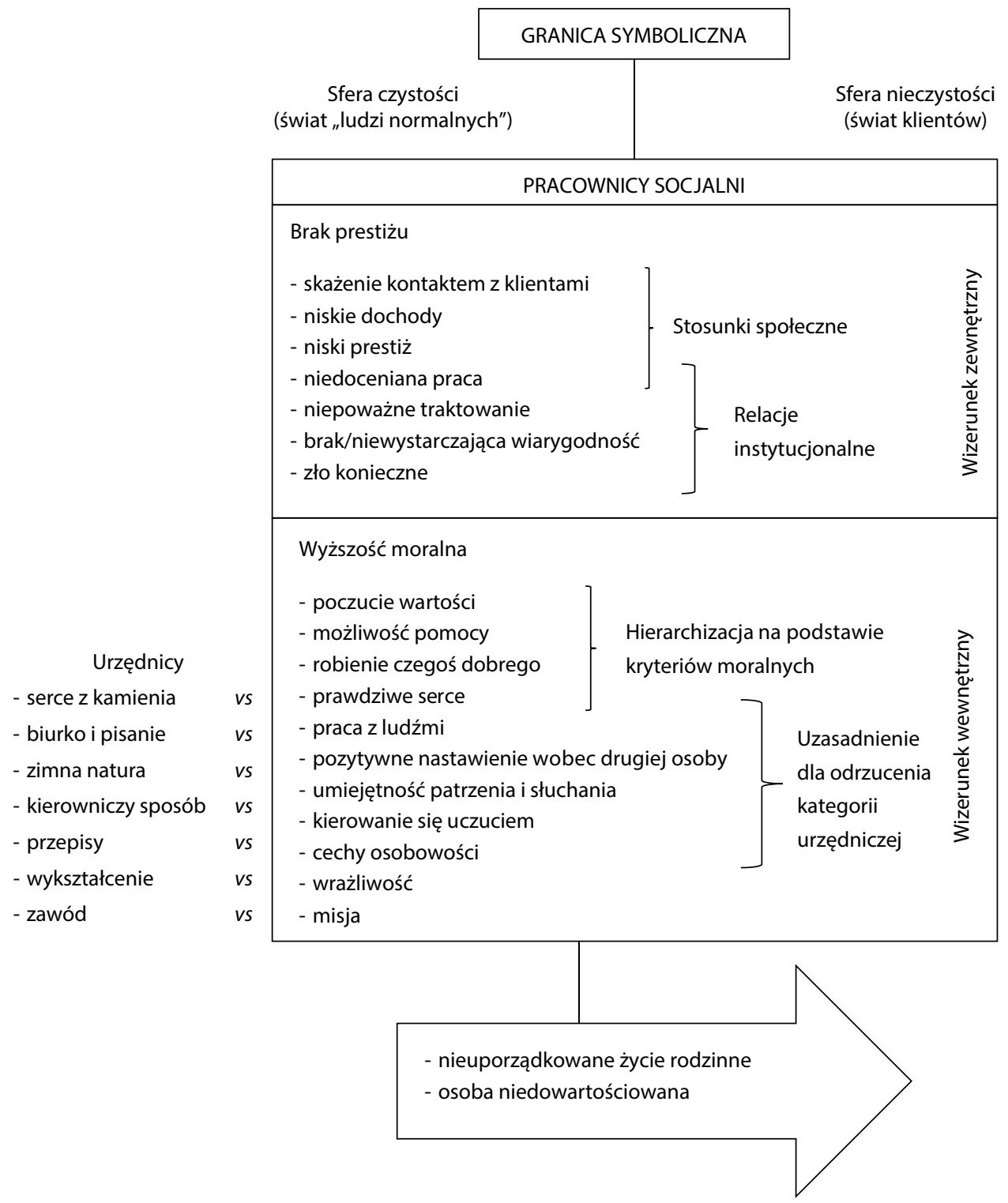

Schemat 1. Ulokowanie pracowników socjalnych w kontekście granicy symbolicznej

Źródło: Opracowanie własne. 
Podczas analizy tożsamości pracowników socjalnych konieczne jest wzięcie pod uwagę nie tylko względnej pozycji w przestrzeni społecznej, lecz przede wszystkim zewnętrznego i wewnętrznego momentu tożsamości (zgodnie z teorią Jenkinsa).

Relację między oboma wizerunkami Jenkins opisuje następująco:

\begin{abstract}
Mobilizując kompetencje interakcyjne w rutynach sytuacyjnych (ramach), jednostki prezentują obraz siebie - jaźni - do akceptacji przez innych. W moim nazewnictwie jest to wewnętrzny moment dialektyki tożsamości w stosunku do wizerunku publicznego. Zewnętrznym momentem jest recepcja tej prezentacji przez innych: mogą ją przyjąć lub nie. Indywidualna tożsamość wyłania się z trwających relacji autowizerunku i publicznego wizerunku [tłum. Ł.T.] (Jenkins 2008: 93).
\end{abstract}

Analiza uzyskanego materiału zgodnie z przyjętymi założeniami teoretycznymi pozwala na postawienie tezy, że ów dialektyczny związek w przypadku pracowników socjalnych jest nacechowany napięciem i pewną niezgodnością obydwu wizerunków. Otóż wizerunek zewnętrzny pracowników socjalnych budzi ich opór i propozycję przeciwstawienia alternatywnego wizerunku własnego (Schemat 1).

\title{
Wizerunek zewnętrzny, czyli niski prestiż
}

Wizerunek zewnętrzny doświadczany przez pracowników w interakcjach jest związany z granicą symboliczną, do której się odwołują. Swoistym paradoksem owej granicy jest to, że mechanizmy rozróżnień odwołujące się do sfer czystości i nieczystości, którymi pracownicy socjalni posługiwali się wobec klientów, są przywoływane wobec nich samych. Pracownicy socjalni, przekraczając w swojej pracy granicę między światami czystości i nieczystości, dla świata społecznego „ludzi normalnych” pozostają sferą zanieczyszczoną, sferą skażoną. Kontakt z tym, co nieczyste, obniża prestiż zawodu i przyczynia się to - $w$ rozumieniu badanych - do niskiej pozycji i negatywnego wizerunku. Skrajną formą negatywnego wizerunku zewnętrznego doświadczanego przez badanych była pogarda: „[...] niektórzy, tak jak mówię, niektórzy może mają nas za nic” (PS 5).

Elementem, który wpisuje się w ten negatywny wizerunek, są, wspomniane już, niskie dochody tej grupy zawodowej. Sami pracownicy wskazują w wypowiedziach związek między niskimi zarobkami a niedocenianiem ich pracy. Szczególnie dotkliwe dla badanych jest porównanie pod tym względem z klientami:

Kiedy wypłacam klientom świąteczne, pod koniec roku się kumulują takie różne dodatki, to czasem sama mam mniej na pasku. To są takie momenty, kiedy się zastanawiam. Myślę, że to ten system, to jest wszystko na głowie postawione (PS 39).

Można więc dostrzec analogię $\mathrm{w}$ relacjach związanych $\mathrm{z}$ wykorzystywaną granicą symboliczną, ponieważ wraz z klientami pracownicy socjalni znajdują się w sferze, dla której „nie warto” poświęcać nakładów. Dla badaczy zaskakujące były analogie między 
używanymi określeniami, którymi badani posługiwali się w kategoryzowaniu klientów i podtrzymywaniu granicy symbolicznej, a pełnymi żalu refleksjami nad tym, jak postrzegani przez świat zewnętrzny są sami pracownicy socjalni. Innymi słowy, dla wielu badanych brak prestiżu ich zawodu wiąże się z tym, że wraz z klientami są klasyfikowani jako sfera zmarginalizowana i niepożądana, jako „zło konieczne” (PS 13).

Trzeba jednak wyraźnie zaznaczyć, że kwestia prestiżu zawodu jest zróżnicowana w zależności od wielkości miejscowości, w której badani pracują. W dużych miejscowościach, dzięki pewnej anonimowości, pracownicy mniej doświadczają odrzucenia przez otoczenie społeczne („traktowania jak trędowaci”), silniej jednak odczuwają swój niski status. Odwrotnie zależności te ujawniają się w małych ośrodkach, gdzie znajomość profesji pracownika socjalnego jest powszechna, a co za tym idzie w większym stopniu spotykają się oni z pewną izolacją społeczną:

bo to jest wstyd, że się zna pracownika socjalnego [...]. I tak samo jest na spotkaniach rodzinnych. Jest się traktowanym [jakby się było - uzup. Ł.T.] trędowatym (PS 13).

Jednocześnie w niewielkich miejscowościach w mniejszym stopniu odczuwany jest niski prestiż zawodu.

Najsilniej, niezależnie od wielkości miejscowości, poczucie niskiego prestiżu ujawnia się w interakcjach z innymi instytucjami:

Chciałabym być bardziej poważnie traktowana w sytuacjach, kiedy wzywam pogotowie na przykład do podopiecznego... czy policję, bo sytuacja jakaś taka patowa. Generalnie jestem zbywana w wielu różnych takich sytuacjach i to jest droga przez mękę (PS 29).

Pracownicy socjalni w większości narzekali na współpracę z innymi instytucjami oraz przedstawicielami innych zawodów (placówki służby zdrowia, jednostki oświatowe, sądy, prokuratura czy policja). W wypowiedziach dominuje poczucie traktowania z góry, niedoceniania pracy wykonywanej przez pracowników socjalnych czy wręcz "niepoważnego traktowania”:

osoba pracownika socjalnego nie jest wiarygodna dla sądu, to jest bardzo trudne. Nie jest wiarygodna dla prokuratury, jest traktowana jak przechodzień, zwykły świadek i to mnie najbardziej drażni (PS 13). Więc no... z policją też bywa różnie, myślę, że policjanci niezbyt poważnie traktują nasze prośby, chociażby o wspólne wejścia w środowisko (PS 1).

Najsilniej wizerunek zewnętrzny, utożsamiany przez badanych z brakiem prestiżu, jest przez nich doświadczany w relacjach $\mathrm{z}$ instytucjami otoczenia, $\mathrm{z}$ którymi wchodzą w kontakt. Jednocześnie hierarchia, w której zajmują oni pozycję względnie niską, jest przez nich uznawana za naturalną. Pracownicy socjalni często wskazują, iż odwoływanie się do innych instytucji jest konieczne z racji ich niskiej pozycji, równocześnie jednak 
z szacunkiem traktują przedstawicieli innych zawodów (np. policjantów), z których pomocy zmuszeni są korzystać.

Ponownie można dostrzec zaskakujące analogie między stosunkiem pracowników socjalnych do klientów (np. określanie części klientów jako „niewiarygodnych”) a tym, jak sami są traktowani w relacjach $z$ otoczeniem instytucjonalnym pomocy społecznej. Niski prestiż w kontekście instytucjonalnym przekłada się wprost na, jak nazywają to sami badani, „niewielką wiarygodność pracowników socjalnych” wśród innych organów czy wręcz „niepoważne traktowanie” ich pracy i ich samych. Pracownicy socjalni nie funkcjonują więc jako równorzędni partnerzy w tych relacjach, co stanowi dla nich źródło ciągłej frustracji. Często wspominali, że czują się traktowani jak petenci, intruzi o niewielkiej wiarygodności, którzy muszą ją dopiero udowodnić.

Podsumowując: wizerunek zewnętrzny swojej grupy zawodowej, którego doświadczają pracownicy socjalni zarówno w przypadku kontaktu z innymi instytucjami, jak i w szerszym środowisku społecznym, jest w odczuciu badanych nieprawdziwy i krzywdzący. Elementy owego wizerunku, które budziły opór badanych, okazały się bardzo podobne do oceny tych klientów, od których pracownicy socjalni chcieli się najbardziej zdystansować. Jeśli odwołamy się do koncepcji granicy symbolicznej, opartej na opozycji czystości i nieczystości, możemy zauważyć dwojaką pozycję pracowników socjalnych. W odniesieniu do klientów pracownicy samych siebie lokowali po przeciwnej stronie granicy czyste/nieczyste. Sami doświadczali wizerunku pracowników socjalnych, który co prawda koncentrował się na niskim prestiżu tego zawodu, ale w opisywanych doświadczeniach badanych przypominał wizerunek klientów. Tym samym znajdowali się po tej samej stronie granicy czyste/nieczyste co klienci. Odzwierciedla się to w podobnych postawach pracowników wobec swoich klientów i (doświadczanych) postawach przedstawicieli innych zawodów oraz instytucji wobec pracowników socjalnych. Takie właśnie postawy są źródłem frustracji i dystansowania się od owego wizerunku zewnętrznego (jako nieprawdziwego i krzywdzącego). Trzeba pamiętać, że wizerunek zewnętrzny jest doświadczany przez pracowników socjalnych w praktyce życia codziennego, w interakcjach. Przekonanie o pewnym określonym obrazie wizerunku zewnętrznego staje się realne w swoich skutkach i prowadzi do przeciwstawienia alternatywnego obrazu grupy własnej.

\section{Wizerunek wewnętrzny, czyli wyższość moralna}

Wizerunek zewnętrzny własnej grupy zawodowej, którego doświadczają pracownicy socjalni w interakcjach, budzi ich opór. Terminem opór (resistance) posługiwał się Jenkins w celu wyjaśnienia elementów wizerunku zewnętrznego w kategoriach dominacji i narzucania niepożądanych kategoryzacji oraz sprzeciwu, jaki rodzi to po stronie oznaczonych za pomocą owych narzuconych kategorii (Jenkins 2008: 47). Zgodnie z zaproponowanym przez niego modelem tożsamości społecznej sposobem, w jaki jednostki radzą sobie $z$ narzuconymi kategoryzacjami, jest odrzucenie zewnętrznego wizerunku 
i przeciwstawienie wizerunku wewnętrznego opartego na odmiennych zasadach wartościowania i klasyfikacji.

Rekonstrukcja wizerunku wewnętrznego pracowników socjalnych przebiegła w dwóch wymiarach. Najpierw odbywała się w odniesieniu do wizerunku zewnętrznego. Spodziewanym rezultatem analizy było uzyskanie przeciwstawnych wizerunków. Jeśli więc wizerunek zewnętrzny doświadczany był jako oparty na niskim prestiżu zawodu i klasyfikowaniu wraz z klientami do sfery pomocy społecznej (co znajdowało odbicie w odczuwanym traktowaniu pracowników socjalnych przez przedstawicieli innych instytucji analogicznie do tego, jak pracownicy postrzegali część klientów), to można było oczekiwać, że wizerunek zewnętrzny będzie się koncentrował wokół kwestii prestiżu zawodu (a więc elementów pozwalających na podniesienie go w oczach własnych, a także innych grup, np. profesjonalnego przygotowania niezbędnego w tej profesji, statusu urzędnika), jak i dystansowania się od klientów (a więc podkreślania różnic między klientami a pracownikami społecznymi). Innymi słowy, kryterium wartościowania, które spodziewano się odkryć w trakcie analizy materiału, powinno opierać się na kapitale kulturowym ${ }^{8}$.

Uzyskane wyniki nie były jednak zgodne z tymi oczekiwaniami. Zamiast spodziewanego utożsamiania się pracowników socjalnych z pozycją urzędnika zaobserwowano zaskakująco silne dystansowanie się od tego statusu.

O! Pierwsza zasada, pracownik socjalny nie jest urzędnikiem i nie jest tak postrzegany przez klientów pomocy społecznej. Nie jesteśmy postrzegani jako urzędnicy [...]. Jeżeli ty chodzisz za kimś po polu, ganiasz gdzieś po łące, czy za przeproszeniem wchodzisz w gumowcach $\mathrm{w}$ takie wielkie błoto, albo dajmy na to coś innego, no to [...] nie ma czegoś takiego, że pracownik socjalny, moim zdaniem, jest traktowany jak urzędnik i nie ma takiego prestiżu (PS 13).

Przytoczona wypowiedź reprezentuje bardzo liczną klasę zakodowanych w trakcie analizy wypowiedzi pracowników socjalnych odnoszących się do urzędników. Warto tutaj podkreślić, że w przeciwieństwie do porównań z klientami, które zostały wywołane przez pytania zadawane w trakcie wywiadu, odniesienia do urzędników były przytaczane przez badanych spontanicznie. Co więcej, analiza tych wypowiedzi jednoznacznie wskazywała na symbolicznie budowany dystans. Nie tylko w rozumieniu takim, jak w powyższym cytacie, w którym pracownik socjalny wskazuje, iż nie jest postrzegany jako urzędnik (mimo formalnego statusu), lecz przede wszystkim w osi rozróżnień my (pracownicy socjalni) - oni (urzędnicy). Ponownie można zaobserwować nakładanie się klasyfikacji, w której pozytywny biegun niemal wszystkich odnotowanych wypowiedzi

${ }^{8}$ W istocie bowiem granica czyste/nieczyste może być rozpatrywana w kategoriach różnic zasobów kapitału kulturowego, gdyż klasyfikowanie obiektów zgodnie z tym podziałem pokrywa się z obserwowanymi w antropologii podziałami na to, co kulturowo akceptowane, i to, co kulturowo jest odrzucane (Douglas 2007). 
przypisywany jest grupie własnej (pracownikom socjalnym), a biegun negatywny grupie obcej (urzędnikom).

[...] nas interesuje praca socjalna z ludźmi, na rzecz ludzi, są też urzędnicy, których interesuje biurko i pisanie czy księgowość lub coś [podobnego - uzup. Ł.T.] (PS 3).

Owe kategoryzacje przebiegają między pracą socjalną a pracą biurokratyczną, między pracownikiem socjalnym a urzędnikiem, między światem pomocy a światem reguł, światem ludzkim a światem nieludzkim.

Uważam, że to daje, jak gdyby, poczucie takiej wartości, godności, że mogę komuś pomóc, tej etyki zawodowej, że mogę się wypowiedzieć fajnie o kimś, że ktoś o mnie, że mam serce, takie nie z kamienia, jak to niektórzy mówią, że ktoś tam ma serce z kamienia, pracownik urzędowy, prawda, my, o nas chyba tego nie można powiedzieć (PS 3).

Prawdziwe serce pracownika socjalnego zostaje przeciwstawione urzędniczemu sercu z kamienia, co narzuca odczytanie pozostałych cech: pracownika socjalnego, który czyni dobro, i urzędnika, który nawet jeśli nie czyni zła, to nie robi niczego dobrego. Nie pomaga, nie pomaga prawdziwie, jak tylko pomóc może pracownik socjalny:

Satysfakcjonujące jest, że jak to mi kiedyś moja koleżanka księgowa powiedziała: ja tylko liczę liczby i nic z tego nie wynika, natomiast ty możesz coś zrobić dobrego. I to jest satysfakcjonujące, jak się naprawdę komuś pomoże (PS 9).

Prawdziwa pomoc staje się tu działaniem sensownym, o pozytywnej wartości moralnej i przeciwstawiona jest pracy bezsensownej, amoralnej. W ten sposób analiza ujawnia istotę kryterium wartościowania stosowanego przez pracowników socjalnych w odniesieniu do dystynkcji od urzędników i pracy biurokratycznej. Tym kryterium jest wyższość moralna pracowników socjalnych nad innymi profesjami, a nad urzędnikami w szczególności.

O ile więc granica między pracownikami socjalnymi a przynajmniej częścią klientów była oparta na kryteriach kulturowych, o tyle w przypadku odróżnienia pracowników od urzędników przywołane zostało moralne kryterium wartościowania.

To podtrzymywanie rozróżnienia między pracownikami a urzędnikami ma także swój dodatkowy wymiar, który zaobserwowano w przypadku pytań o pracę. Pracownicy socjalni bowiem w dużym stopniu stają się w praktyce dnia codziennego urzędnikami, a sfera biurokratyczna związana $\mathrm{z}$ wypełnianiem dokumentacji i wydawaniem decyzji administracyjnych zastępuje w coraz większym zakresie faktyczną pracę socjalną, pracę z klientem i poszukiwanie sposobów pomocy oparte na wiedzy teoretycznej z dziedziny pomocy (Granosik 2011, 2012; Rymsza 2011). Stawiając urzędników w kontrze do pracowników socjalnych, ci ostatni jednoznacznie odróżniają swoje role zawodowe, stosując właśnie kategorie moralne do budowania różnicy. Ma to szczególne przełożenie 
na zaobserwowane w wywiadach dystansowanie się od administracyjnych aspektów roli (nazywanych pejoratywnie „papierkami”). Innymi słowy, można zauważyć zgodność między negatywnym wartościowaniem urzędników (w odniesieniu do własnej profesji) a negatywnym stosunkiem do administracyjno-urzędniczych aspektów swojej roli zawodowej. Istotne dla zrozumienia wewnętrznego wizerunku jest więc skoncentrowanie się na tych aspektach autowizerunku grupy zawodowej, które są wartościowane dodatnio, uznawane za element zasadniczy i wpisywane we wzorzec osobowy pracowników socjalnych.

Respondenci pytani o to, jaki powinien być pracownik socjalny, wskazywali najczęściej na umiejętność słuchania, empatię, komunikatywność, gotowość do pomocy/chęć pomocy i pozytywne nastawienie do ludzi. Żadna z tych cech nie ma bezpośredniego przełożenia na sferę biurokratyczną. Równie ważne jest jednak to, jakie cechy nie były przywoływane. W wywiadach właściwie nie było deklaracji odnoszących się do profesjonalizmu, wiedzy specjalistycznej, podnoszenia kompetencji, samorozwoju. Innymi słowy, kryteria wskazywane w momencie określania wzorca osobowego pracowników socjalnych nie zawierają elementów, które można wiązać z profesjonalizacją zawodu. Wręcz przeciwnie, specjalistyczna wiedza (teoria) i przygotowanie do zawodu są często kwestionowane:

Nie każdy może być pracownikiem socjalnym, nawet jeżeli zdobędzie superwykształcenie, super się wykształci, to pewnie trzeba mieć, no nie wiem no, trzeba na pewno wiele pokory, trzeba często się, nie wiem, tak zmierzyć z jakimiś tam własnymi ograniczeniami. Na pewno trzeba posiadać takie cechy osobowości, które no, nie skrzywdzą drugiego człowieka (PS 22).

Zamiast profesjonalnego przygotowania i specjalistycznej wiedzy w wypowiedziach badanych pojawiają się cechy osobowości. Znów pobrzmiewają w opiniach pracowników socjalnych echa różnic między nimi a urzędnikami. Urzędnikiem może zostać każdy, kto tylko spełni kryteria formalne, a praca socjalna nie jest dla każdego, właśnie dlatego, że „trzeba mieć to coś w sobie” (PS 26). Rozróżnienie przebiega więc nie tylko w sferze moralnej, lecz także osobowościowej. Przy czym obydwie zasady kategoryzacyjne są komplementarne, ponieważ owe cechy osobowościowe obejmują uczucia niezbędne w tej pracy:

Najlepiej by było, jakby to nie były osoby, które tego nie czują, to muszą być też - moim zdaniem - osoby wrażliwe. [...]. Jeżeli się człowiek odpowiednio wczuje w daną sytuację i tam jakoś się ma takie predyspozycje wewnętrzne, że jest wrażliwy i potrafi zapłakać, i do tańca, i do różańca, to myślę, że bardziej mógłby się nadać, tylko to trzeba czuć (PS 34).

Nakładające się klasyfikacje oparte są na uczuciach, cechach osobowościowych i kategoriach moralnych: urzędnicy z „sercem z kamienia” przeciwstawieni są pracownikom socjalnym obdarzonym „prawdziwym sercem”, które pozwala im „czuć” to, czego nie 
poczują inni. Trzeba więc dyspozycji etycznej, dyspozycji do pełnienia swoistej misji moralnej „pomagacza”:

Myślę, że też chyba trochę trzeba czuć, to jest taki jeden z zawodów tych tak zwanych pomagaczy, że z marszu nie mogę pomóc [...], ale myślę, że trzeba trochę czuć tę pracę, żeby dobrze [ją uzup. Ł.T.] wykonywać (PS 36).

Elementem owych klasyfikacji staje się więc ogólny cel życia: misja moralna niesienia pomocy przeciwstawiana karierze zawodowej. Zdaniem badanych pracownikiem socjalnym nie może zostać:

osoba, która nie chce pomagać, która traktuje to tylko jako zawód i kwestię zarabiania pieniędzy, albo osoba, nie wiem, która upatruje tutaj jakiejś kariery zawodowej i dużej gratyfikacji finansowej (PS 20).

Praca socjalna jest więc zadaniem, które mogą podjąć jedynie osoby obdarzone szczególnymi cechami, kierujące się sercem, a nie twardymi regułami, spieszące z pomocą, nie myśląc o sobie, o własnych potrzebach. Innymi słowy, w wypowiedziach badanych pojawia się różnica między powołaniem a zawodem. W szerszym wymiarze społeczno-kulturowym wpisuje się to rozróżnienie powołania i moralnej misji w tradycyjny inteligencki etos troski o „prosty lud” przeciwstawiony karierze typowej dla klas średnich (professions). Owa misja jest elementem całościowej tożsamości sięgającej dalej niż zwyczajne wykonywanie pracy. Większość badanych pracowników socjalnych deklarowała bowiem, że cały czas jest zaangażowana w pomoc: bez względu na to, czy jest na urlopie, czy po godzinach pracy. Powołanie jest bowiem czymś, co przenika całą sferę życia jednostki i dlatego „czasami myśli cały czas o tych swoich podopiecznych” (PS 14).

\section{Konkluzja}

Rekonstrukcja wizerunku wewnętrznego i zewnętrznego w kontekście wewnętrzno-zewnętrznej dialektyki tożsamości pozwala na postawienie określonych wniosków. Doświadczenia pracowników socjalnych związane z wizerunkiem zewnętrznym (opartym na niskim prestiżu i postrzeganiu poprzez kontakt z klientem), którego nie akceptują, prowadzi do zaproponowania alternatywnej kategoryzacji opartej na kryteriach moralnych. Węzłowym problemem jest wyznaczenie przez pracowników socjalnych nie tyle granicy wobec klientów, czy przynajmniej ich części (bowiem to wiąże się z budowaniem dystansu i podtrzymywaniem swoistego ładu czystości i nieczystości), ile odróżnienie się symboliczne od urzędników. Jest to zaskakująca sytuacja, gdyż w miejsce kryteriów kulturowych wprowadzone zostają kryteria moralne, które pozwalają przeciwstawić się narzuconemu kategoryzowaniu pracowników (np. przez przedstawicieli otoczenia instytucjonalnego czy społeczności lokalnej) wraz z klientami po stronie nieczystej 
(np. wspominane przez badanych „prątkowanie”). Przeciwstawiony takim narzuconym kategoriom jest wizerunek grupy własnej oparty na wyższości moralnej wynikającej z pełnienia misji społecznej w imię wyższego dobra. A zatem kontakt $\mathrm{z}$ klientem nie musi być stygmą, ale źródłem dumy z pełnionej misji moralnej. Innymi słowy, dochodzi do symbolicznego odwrócenia narracji: to urzędnicy musieliby wyjaśnić, dlaczego zdradzili etos inteligencki, dlaczego wybrali karierę zamiast prawdziwego pomagania innym.

Taki wizerunek wewnętrzny pełni, zdaniem Jenkinsa, podwójną funkcję: pozwala przeciwstawić obraz grupy własnej na zewnątrz, a jednocześnie na poziomie jednostek umożliwia poradzenie sobie z narzuconymi kategoryzacjami i wytworzenie pozytywnego obrazu samych siebie. Na poziomie interakcyjnym zaś owe wizerunki ulegają nie tylko werbalizacji, lecz także są przedmiotem negocjacji. Poziom instytucjonalny jest już związany z trajektorią grupy w strukturze społecznej (wymiar temporalny). Skuteczne narzucenie wizerunku własnego może bowiem prowadzić do poprawy pozycji danej kategorii zawodowej w czasie (trajektoria wznosząca).

Skutkiem przyjętego przez pracowników socjalnych własnego wizerunku jest odrzucenie kryterium kariery zawodowej jako elementu budowania pozycji jednostki. Wyższość pracowników socjalnych jest zakorzeniona w ich niezbywalnych cechach osobowościowych, których nie można nabyć i które nie wymagają dodatkowych starań. Wykształcenie kierunkowe czy wiedza specjalistyczna bywają wprost odrzucane (znamienne przeciwstawienie dokonane przez jedną z respondentek świetnych pracownic socjalnych, które nie robiły wcześniej żadnych kursów, kiepskim młodym pracownikom socjalnym po studiach magisterskich). Wynik ten zbieżny jest $\mathrm{z}$ wcześniejszymi badaniami, w których pracownicy socjalni wskazywali na nieprzydatność wiedzy teoretycznej i wyższość doświadczenia zawodowego (Łuczyńska 2011). Oznacza to więc odrzucenie trajektorii profesjonalizacji pracy socjalnej rozumianej jako specjalizacja $\mathrm{w}$ zakresie pracy z osobami niesamodzielnymi i niezaradnymi życiowo.

Prezentowany przez badanych autowizerunek jest równie daleki od profesjonalnej pracy socjalnej, jak i pracy biurokratycznej (badani wyraźnie i stanowczo dystansowali się od, ich zdaniem, niepotrzebnych „papierków”). W to miejsce przywoływana jest swoiście rozumiana misja moralna, będąca mieszaniną polskiego etosu inteligenckiego (w ikonicznych postaciach Judyma i „siłaczki”) oraz typowego dla początków pomocy społecznej charytatywnego „pomagacza” kierującego się porywem serca. Tym samym impas dostrzegany przez badaczy, dotyczący rozdźwięku między profesjonalnym przygotowaniem a administracyjno-biurokratyczną treścią pracy (Granosik 2012; Rymsza 2012; Kaźmierczak 2012), zostaje na poziomie tożsamości zniesiony, ponieważ obydwa bieguny opozycji są jednakowo odrzucane przez pracowników socjalnych.

Można też sformułować konkluzję w trybie przypuszczającym. Jeśli profesjonalizacja pracy socjalnej miałaby być elementem pozwalającym na wejście pracowników na trajektorię wznoszącą w strukturze społecznej (podobną ścieżką podążyły inne zawody), to wizerunek własny oparty na roli obdarzonego misją moralną "pomagacza” wydaje się tu nieskuteczny dla podniesienia prestiżu zawodu. Jest natomiast aktywną odpowiedzią na wizerunek zewnętrzny oparty na niskim prestiżu właśnie. Można więc 
postawić pytanie: czy mamy w takim razie do czynienia z sytuacją zamknięcia (lock-in) możliwości zmiany wizerunku i pośrednio pozycji pracowników społecznych?

\section{Bibliografia}

Bourdieu P. (2005). Dystynkcja. Społeczna krytyka władzy sądzenia, tłum. P. Biłos. Scholar, Warszawa.

Brągiel J., Kurcz A. (red.) (2002). Pracownik socjalny. Wybrane problemy zawodu w okresie transformacji społecznej. Wydawnictwo Uniwersytetu Opolskiego, Opole.

Douglas M. (2007). Czystość i zmaza, tłum. M. Bucholc. PIW, Warszawa.

Goffman E. (2005). Piętno. Rozważania o zranionej tożsamości, tłum. A. Dzierżyńska, J. Tokarska-Bakir. GWP, Gdańsk.

Granosik M. (2006). Profesjonalny wymiar pracy socjalnej. Wydawnictwo Śląsk, Katowice.

Granosik M. (2011). Rekonstrukcja uwarunkowań możliwości przekształceń/zmian organizacji codziennej pracy socjalnej w miejskich i gminnych ośrodkach pomocy społecznej, w: M. Dudkiewicz (red.), Pracownicy socjalni pomiędzy instytucja pomocy społecznej a środowiskiem lokalnym. Instytut Spraw Publicznych, Warszawa: 87-125.

Granosik M. (2012). „Mówię, jak jest, robię co mi każa” - o interpretacyjnym rozdarciu wspótczesnego pracownika socjalnego, w: M. Rymsza (red.), Pracownicy socjalni i praca socjalna w Polsce. Między stużba społeczna a urzędem. Instytut Spraw Publicznych, Warszawa: 187-201.

Jenkins R. (2008). Social Identity: Key Ideas. Routledge, Oxon.

Kaźmierczak T. (2011a). Nowe tendencje w metodyce pracy socjalnej, w: M. Grewiński, J. Krzyszkowski (red.), Współczesne tendencje w pomocy społecznej i pracy socjalnej. WST TWP, Warszawa: 60-67.

Kaźmierczak T. (2011b). Pracownicy socjalni wobec nowych ról zawodowych, w: M. Rymsza (red.), Czy podejście aktywizujące ma szansę? Pracownicy socjalni i praca socjalna $w$ Polsce 20 lat po reformie systemu pomocy społecznej. Instytut Spraw Publicznych, Warszawa: 143-165.

Kaźmierczak T. (2012). Pracownicy socjalni, kapitał ludzki, profesjonalna praktyka, w: M. Rymsza (red.), Pracownicy socjalni i praca socjalna w Polsce. Między służba społeczna a urzędem. Instytut Spraw Publicznych, Warszawa: 159-186.

Kromolicka B. (2011). Kształcenie do pracy socjalnej w Polsce - praktyka codzienności, w: K. Piątek, K. Szymańska-Zybertowicz (red.), Profesjonalna praca socjalna. Nowy paradygmat czy niedokończone zadanie?. Wydawnictwo Edukacyjne „Akapit”, Toruń: 121-132.

Lamont M. (1992). Money, Morals and Manners: The Culture of the French and American Upper-Middle Class. The University of Chicago Press, Chicago-London.

Lamont M. (1995). National Identity and National Boundary Patterns in France and the United States. „French Historical Studies”, 19, 2: 349-365.

Lamont M. (2000). The Dignity of Working Man: Morality and the Boundaries of Race, Class and Immigration. Russell Sage Foundation, New York.

Lamont M. (2001). Culture and Identity, w: J.H. Turner (red.), Handbook of Sociological Theory. Kluwer Academia/Plenum Publishers, New York: 171-185. 
Lamont M., Thévenot L. (2000). Rethinking Comparative Cultural Sociology: Polities and Repertoires of Evaluation in France and the United States. Cambridge University Press, New York. Lewicki M. (2016). Klasy w postnarodowych społeczeństwach. Socjologia klas według Michèle Lamont. „Studia Socjologiczno-Polityczne”, Seria Nowa 1-2 (03): 31-54.

Łuczyńska M. (2011). Wybrane elementy orientacji zawodowej i sytuacji społecznej pracowników socjalnych, w: M. Rymsza (red.), Czy podejście aktywizujące ma szansę? Pracownicy socjalni i praca socjalna $w$ Polsce 20 lat po reformie systemu pomocy społecznej. Instytut Spraw Publicznych, Warszawa: 45-107.

Matyjas B., Porąbaniec M. (red.) (2008). W drodze ku profesjonalizacji zawodu pracownika socjalnego. Wydawnictwo Akademii Świętokrzyskiej, Kielce.

Rataj B. (2007). Profesjonalizacja zawodu pracownika socjalnego w Polsce, w: K. Piątek, A. Karwacki (red.), Aktywna polityka społeczna z perspektywy Europy socjalnej. Wydawnictwo Edukacyjne „Akapit”, Toruń: 467-478.

Rymsza M. (2011). W stronę profesjonalizacji pracy socjalnej? Wnioski końcowe, w: M. Rymsza (red.), Czy podejście aktywizujace ma szansę? Pracownicy socjalni i praca socjalna $w$ Polsce 20 lat po reformie systemu pomocy społecznej. Instytut Spraw Publicznych, Warszawa: 235-253.

Rymsza M. (2012). Praca socjalna, stużby społeczne, pomoc społeczna w Polsce. Stan obecny i perspektywy rozwoju, w: M. Rymsza (red.), Pracownicy socjalni i praca socjalna w Polsce. Między służba społeczna a urzędem. Instytut Spraw Publicznych, Warszawa: 353-365.

Szmagalski J. (2011). Profesje we wspótczesnej perspektywie teoretycznej a wyzwania profesjonalizacji pracy socjalnej w Polsce, w: K. Piątek, K. Szymańska-Zybertowicz (red.), Profesjonalna praca socjalna. Nowy paradygmat czy niedokończone zadanie?. Wydawnictwo Edukacyjne „Akapit”, Toruń: 17-35.

Szmagalski J. (2012). Kształcenie do pracy socjalnej w Polsce po 1989 roku, w: M. Rymsza (red.), Pracownicy socjalni i praca socjalna $w$ Polsce. Między służba społeczna a urzędem. Instytut Spraw Publicznych, Warszawa: 279-297.

Trawkowska D. (2006). Portret współczesnego pracownika socjalnego. Studium socjologiczne. Wydawnictwo Śląsk, Katowice.

Woźniak Z. (1998). Praca socjalna - między zawodem a profesją, w: H. Gąsior, A. Słaboń (red.), Pracownik socjalny jako profesjonalista. MOPS, Katowice: 19-27.

Wódz K. (1998). O znaczeniu pojęcia „profesjonalizm” we wspótczesnej pracy socjalnej, w: H. Gąsior, A. Słaboń (red.), Pracownik socjalny jako profesjonalista. MOPS, Katowice: 28-34.

Wódz K. (1999). Profesjonalizm jako podstawowy wyznacznik tożsamości zawodowej pracownika socjalnego, w: A Niesporek, K. Wódz (red.), Praca socjalna w Polsce. Badania, kształcenie, potrzeby praktyk. Wydawnictwo Śląsk, Katowice: 135-147.

Wódz K., Faliszek K. (red.) (2010). Przeobrażenia w pomocy społecznej a edukacja i doskonalenie zawodowe pracowników socjalnych w Polsce i Republice Słowackiej. Wydawnictwo Edukacyjne „Akapit”, Toruń.

Zasada-Chorab A. (2004). Kształtowanie się zawodu pracownika socjalnego w Polsce. Centrum AV, Częstochowa. 